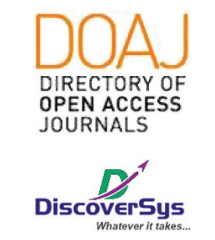

Published by DiscoverSys

\title{
Efek pemberian kombinasi jus aloe vera dan glibenklamid terhadap penurunan kadar glukosa darah pada model tikus diabetes yang diinduksi dengan streptozotosin dan nikotinamid
}

\author{
I Kadek Dwi Iman Muliawan ${ }^{1,2 *}$
}

\begin{abstract}
Introduction: Antidiabetic oral was not optimal for reducing blood glucose, patients use the various antidiabetic herbs along with antidiabetic drug for controlling their blood glucose level. Aloe vera is one of the plants that are often used by diabetic patients who are also taking antidiabetic medication and susceptible arise interaction between them. Objectives of this study is to determine the effect of Aloe vera juice and glibenclamide combination in reducing blood glucose levels in the diabetic rats model induced by streptozotosin and nicotinamide.

into three groups and administered CMC 0,5\%, glibenclamide, or Aloe vera and glibenclamide. The animals were treated orally once daily for twentyeight days. Data were analyzed using one way Anova

Result: Findings of this study indicate that of Aloe vera juice in combination with glibenclamide significantly reduced blood glucose levels significantly in diabetes rats model $(p<0,05)$ Conclusion: Combination of Aloe vera juice and glibenclamide be able to lower blood glucose levels and statistically significant.
\end{abstract}

Method: Research metodology the diabetic rats were randomized

Keywords: Streptozotosin and nicotinamide, combination, glibenclamide, Aloe vera

Cite This Article: Muliawan, I.K.D.I. 2019. Efek pemberian kombinasi jus aloe vera dan glibenklamid terhadap penurunan kadar glukosa darah pada model tikus diabetes yang diinduksi dengan streptozotosin dan nikotinamid. Intisari Sains Medis 10 (2): 527-531. D0l: 10.15562/ism.v10i2.532

\section{ABSTRAK}

${ }^{1}$ Mahasiswa Fakultas Kedokteran Universitas Islam Indonesia ${ }^{2}$ Departemen Farmakologi Fakultas Kedokteran Universitas Islam Indonesia
*Korespondensi:

I Kadek Dwi Iman Muliawan; Mahasiswa Fakultas Kedokteran Universitas Islam Indonesia; Departemen Farmakologi Fakultas Kedokteran Universitas Islam Indonesia

ikadek.dwi.iman@gmail.com
Latar Belakang: Penderita DM diperkirakan meningkat setiap tahunnya dan terkadang penggunaan obat antidiabetik tidak optimal dalam menurunkan glukosa darah. Kondisi ini membuat kebanyakan pasien berinisiatif untuk memanfaatkan tanaman obat yang dianggap berkhasiat untuk menurunkan kadar glukosa darah. Salah satu obat herbal yang sering digunakan adalah Aloe vera. Padahal penggunaan kombinasi obat antidiabetik dengan Aloe vera dapat menimbulkan interaksi. Tujuan Penelitian untuk mengetahui pengaruh kombinasi jus Aloe vera dan glibenklamid dalam menrunkan kadar glukosa darah pada model tikus diabetes yang diinduksi dengan streptozotosin dan nicotinamide.
Metode: Metode Penelitian menggunakan tikus yang diinduksi menjadi diabetes melitus dibagi menjadi 3 kelompok yang menerima perlakuan berupa plasebo CMC 0,5\%, Glibenklamid dan kombinasi jus Aloe vera dan glibenklamid. Perlakuan diberikan setiap hari selama 28 hari. Data dianalisis menggunakan uji One way Anova

Hasil: Hasilnya adalah Kombinasi jus Aloe vera dan glibenklamid signifikan secara statistik menurunkan kadar glukosa darah pada model tikus diabetes $(p<0,05)$.

Simpulan: Kombinasi jus Aloe vera dan glibenklamid mampu menurunkan glukosa darah dan signifikan secara statistik.

Kata Kunci: Streptozotosin dan nikotinamid, Kombinasi, Glibenklamid, Aloe vera

Site Pasal ini: Muliawan, I.K.D.I. 2019. Efek pemberian kombinasi jus aloe vera dan glibenklamid terhadap penurunan kadar glukosa darah pada model tikus diabetes yang diinduksi dengan streptozotosin dan nikotinamid. Intisari Sains Medis 10 (2): 527-531. D0I: 10.15562/ism. v10i2.532

\section{PENDAHULUAN}

Diabetes melitus (DM) atau kencing manis merupakan penyakit kronis yang menjadi masalah utama dalam dunia kesehatan. American Diabetes
Association (ADA) pada tahun 2013 menyatakan bahwa 90-95\% kasus diabetes melitus adalah tipe 2 yang merupakan gangguan metabolik yang ditandai gangguan sekresi insulin pada sel beta dan ketidakmampuan jaringan perifer 
berespon terhadap insulin (resistensi insulin). Badan kesehatan dunia WHO pada tahun 2014 menyatakan bahwa jumlah penderita diabetes di dunia adalah 347 juta dan jumlah ini diprediksi akan meningkat hingga 522 juta pada tahun 2030. ${ }^{1,2}$

Indonesia termasuk dalam sepuluh negara dengan jumlah penderita DM terbanyak di Asia dan menempati posisi ke empat di dunia setelah India, China dan Amerika Serikat Jumlah penderita DM di Indonesia akan terus meningkat tiap tahunnya dan diprediksi terdapat sekitar 21,3 juta penderita DM di Indonesia tahun 2030. ${ }^{1,2}$ International Diabetes Federation (IDF) juga memprediksi kenaikan jumlah penderita DM dari 7,0 juta tahun 2009 menjadi 12,0 juta pada tahun $20300^{3,4}$

Glibenklamid merupakan salah satu obat antidiabetik oral yang sering digunakan. Glibenklamid bekerja merangsang sel $\beta$ pankreas untuk mengeluarkan insulin. Obat antidiabetik memberikan manfaat yang besar bagi penderita DM, tetapi terkadang tidak optimal dalam menurunkan glukosa darah. Kondisi ini seringkali membuat pasien berinisiatif mengkombinasikan obat antidiabetik oral yang diresepkan dokter dengan obat herbal. ${ }^{5}$ Salah satu obat herbal yang sering digunakan sebagai obat DM adalah Aloe vera. Aloe vera memiliki zat aktif berupa kromium dan alprogen. Kedua zat aktif tersebut terbukti memberikan efekterhadap penurunankadarglukosa darah. ${ }^{6}$ Banyak penderita DM mengkombinasikan Aloe vera dengan obat antidiabetik tanpa berkonsultasi sebelumnya dengan dokter. Padahal mengkonsumsi obat antidiabetik lebih dari satu jenis obat berpotensi menimbulkan interaksi, termasuk mengkombinasikan obat sintetik dengan obat herbal. ${ }^{7}$ Salah satu pengolahan gel Aloe vera yang sering beredar di masyarakat yaitu dalam bentuk jus, sebab pembuatan jus Aloe vera mudah untuk dikonsumsi. ${ }^{8}$ Penelitian ini bertujuan untuk mengetahui efek pemberian kombinasi jus Aloe vera dan glibenklamid dibandingkan dengan glibenklamid terhadap penurunan kadar glukosa darah.

\section{METODE PENELITIAN}

Penelitian ini merupakan penelitian eksperimental dengan pendekatan Pretest Posttest with Control Group Design menggunakan hewan percobaan. Penelitian dilakukan di PAU (Pusat Antar Universitas) Universitas Gadjah Mada selama 41 hari. Dalam penelitian dibutuhkan alat sprektofotometer untuk mengukur kadar glukosa darah puasa, timbangan elektrik dan mesin blender. Selain itu, Bahan yang dibutuhkan dalam penelitian berupa glibenklamid dalam bentuk farmagrid serbuk yang disuspensi dengan CMC 0,5
$\%$, Aloe vera dengan jenis Aloe barbedensis milier yang diolah dalam bentuk jus hasil dari gel Aloe vera yang diahsluskan menggunakan mesin blender serta obat sterptozotoisn dan nikotinamid. Subyek dalam penelitian adalah tikus putih jantan (Rattus novergicus) strain wistar dengan umur 2-3 bulan dan berat badan 180- 250 gram. Subyek diperoleh dari laboratorium Pusat Studi Pangan dan Gizi Universitas Gadjah Mada.

Berdasarkan ketentuan WHO yaitu menggunakan jumlah sampel minimal 5 ekor tikus sehingga dibutuhkan 20 tikus putih jantan (Rattus Novergicus) strain wistar yang dikelompokkan secara acak menjadi 4 kelompok. Kelompok I (kontrol normal) adalah tikus sehat tanpa induksi DM yang diberikan plasebo yaitu CMC 0,5\%. Kelompok II (kontrol negatif) adalah tikus DM dan diberikan plasebo yaitu CMC 0,5\%. Kelompok III (kontrol positif) adalah tikus DM dan diberikan glibenklamid 0,18 mg/200 g BB/tikus. Kelompok IV (kelompok perlakuan) adalah tikus DM dan diberikan kombinasi jus Aloe vera 3,6 mg/200 g $\mathrm{BB} /$ tikus dan glibenklamid 0,18 mg/200 g BB/tikus.

\section{Induksi}

Induksi diabetes melitus tipe 2 menggunakan NA (nikotinamid) $230 \mathrm{mg} / \mathrm{kg}$ yang dilarutkan dengan larutan PBS (Phosphat Buffeerd Saline) dan STZ (streptozotosin) dengan dosis $65 \mathrm{mg} /$ $\mathrm{kg}$ dilarutkan dengan buffer sitrat dengan ph 4,5 secara intraperitoneal (ip). ${ }^{9}$

\section{Perlakuan}

Sebelum diberikan perlakuan, tikus diaklimatisasi selama 7 hari. Perlakuan diberikan selama 28 hari dan dimulai pada hari ke-0. Sebelum diberi perlakuan, tikus ditimbang terlebih dahulu untuk menentukan dosis obat glibenklamid dan jus Aloe vera.

\section{Pemeriksaan glukosa darah}

Darah yang diambil dari sinus orbitalis. Sebelum dilakukan pengambilan darah, tikus di anestesi terlebih dahulu secara intramuskular dengan ketamin hidroklorida $20 \mathrm{mg} / \mathrm{kg}$ bb tikus. Pengukuran kadar glukosa darah menggunakan alat spektrofotometer dengan metode GOD-PAP. Metode ini diawali dengan pengambilan darah pada tikus dengan spuit sebanyak $0,5 \mathrm{ml}$ kemudian disentrifus $4000 \mathrm{rpm}$ selama 15 menit. Setelah itu ambil plasma sebanyak 10 mikrolab dan dicampur dengan reagen GOD PAP 1000 mikrolab dengan menggunakan alat vortex, kemudian di inkubasi selama 20 menit dengan suhu 20- 250 C. Tahap terakhir kadar glukosa dibaca dengan gelombang $500 \mathrm{~nm}$. 


\section{Analisis Data}

Analisis hasil glukosa darah selama perlakuan antar kelompok I, II, III dan IV menggunakann uji One Way Anova dilanjutkan uji Pos Hoc Test.

\section{HASIL PENELITIAN}

Selama penelitian didapatkan rerata berat badan tikus secara berkala yang ditunjukan pada gambar

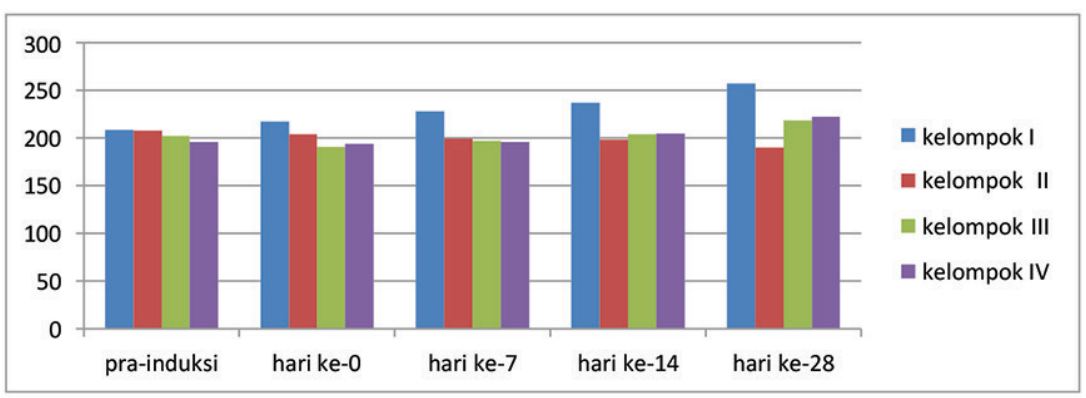

Gambar 1. Rerata berat badan; Keterangan: kelompok I (kontrol normal): tikus sehat + plasebo; kelompok II (kontrol negatif): DM + plasebo; kelompok III (kontrol positif): DM + glibenklamid; kelompok IV (kelompok perlakuan): DM + kombinasi jus Aloe vera dan glibenklamid

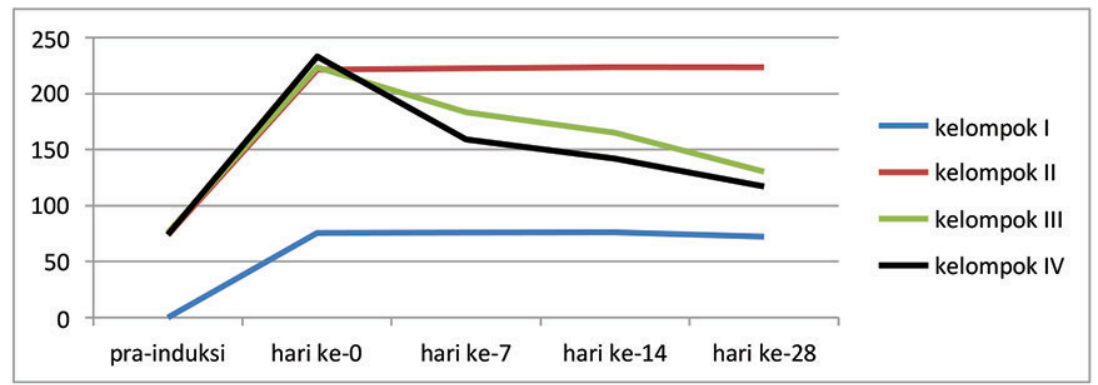

Gambar 2. Kurva penurunan kadar glukosa darah; Keterangan: kelompok I (kontrol normal): tikus sehat + plasebo, kelompok II (kontrol negatif): DM + plasebo, kelompok III (kontrol positif): DM + glibenklamid dan kelompok IV (kelompok perlakuan): DM + kombinasi Jus Aloevera dan glibenklamid.
1.Dari data diatas diperoleh kelompok I terjadi kenaikan berat badan dari pra- induksi sampai post induksi hari ke-28. Kelompok II, III dan IV mengalami penurunan berat badan dari prainduksi dan postinduksi hari ke-0. Sedangkan dari pemeriksaan post-induksi hari ke-0 hingga hari ke-28, kelompok II tetap terjadi penurunan berat badan namun kelompok III dan IV mengalami peningkatan yang stabil setiap pemeriksaan berat badan.

Berdasarkan rerata berat badan tikus prainduksi dapat dikatakan tikus yang mengikuti penelitian memenuhi kriteria yaitu 180-250 gram. Selanjutnya dilakukan analisis kadar glukosa darah antar kelompok menggunakan uji statistik One Way Anova.

Pemeriksaan hari ke-7, kelompok IV (kelompok kombinasi) menunjukan penurunan yang lebih baik dan signifikan secara statistik $(\mathrm{p}<0,05)$ dibandingkan dengan kelompok II (kontrol negatif) dan kelompok III (kontrol positif). Pemeriksaan hari ke-14, kelompok IV (kelompok kombinasi) juga menunjukan penurunan yang lebih baik dan signifikan secara statistik $(\mathrm{p}<0,05)$ dibandingkan dengan kelompok II (kontrol negatif) dan kelompok III (kontrol positif). Sama halnya dengan hari ke-28, kelompok IV (kelompok kombinasi) menunjukan penurunan yang lebih baik dan signifikan secara statistik $(\mathrm{p}<0,05)$ dibandingkan kelompok II (kontrol negatif) dan kelompok III (kontrol positif).

\section{PEMBAHASAN}

Peningkatan kadar glukosa post- induksi hari ke-0 menunjukan peningkatan tiga kali lipat dari pemeriksaan pra- induksi. Hal tersebut disebabkan oleh STZ yang dapat merusak DNA sel $\beta$ pankreas melalui alkilasi fragmen DNA sehingga terjadi gangguan sekresi insulin. Namun NA bersifat proteksi sehingga kerusakan sel $\beta$ akibat STZ tidak meluas. Gangguan sekresi insulin akibat STZ mempunyai dampakpenurunan berat badan

Tabel 1. Rerata kadar gukosa

\begin{tabular}{|c|c|c|c|c|c|c|}
\hline \multirow{3}{*}{ Kelompok } & \multicolumn{6}{|c|}{ Rerata kadar glukosa darah (mg/dl) } \\
\hline & \multicolumn{2}{|c|}{ Pra-induksi } & \multicolumn{4}{|c|}{ Post-induksi } \\
\hline & & & Hari ke-0 & Hari ke-7 & Hari ke-14 & Hari ke28 \\
\hline I & $\mathrm{X} \pm \mathrm{SD}$ & 74,97 & 75,47 & 75,91 & 75,84 & 76,26 \\
\hline II & $\mathrm{X} \pm \mathrm{SD}$ & 73,60 & 221,26 & 222,24 & 223,20 & 223,34 \\
\hline III & $\mathrm{X} \pm \mathrm{SD}$ & 75,86 & 223,39 & 183,44 & 165,22 & 130,43 \\
\hline IV & $\mathrm{X} \pm \mathrm{SD}$ & 73,92 & 233,05 & 159,01 & 141,68 & 117,21 \\
\hline
\end{tabular}

Keterangan: kelompok I (kontrol normal): tikus sehat + plasebo; kelompok II (kontrol negatif): DM + plasebo; kelompok III (kontrol positif): DM + glibenklamid; kelompok IV (kelompok perlakuan): DM + kombinasi jus Aloe vera dan glibenklamid. 
hari ke-0 pada kelompok II, III dan IV. Hal ini dikarenakan gangguan sekresi insulin yang mengakibatkan glukosa tidak dapat digunakan sebagai energi sehingga terjadi lipolisis atau pemecahan lemak. Kehilangan lemak membuat kekurangan bobot tubuh tikus. Kemudian dilihat dari kelompok II, III dan IV yang mendapatkan induksi STZ dan NA, terdapat perbedaan yang mencolok dengan kelompok I pada pemeriksaan gula darah post induksi hari ke-0. Hal tersebut membuktikan kenaikan gula darah di akibatkan oleh induksi yang diterima kelompok II, III dan IV.

Kelompok II yang menerima plasebo 0,5\% tidak menunjukan penurunan glukosa darah dan berat badan meningkat dari hari ke-0 sampai hari ke-28. Hal tersebut dapat dikatakan bahwa CMC $0,5 \%$ tidak mempunyai efek hipoglikemik.

Kelompok III yang menerima perlakuan glibenklamid menunjukan penurunan glukosa yang signifikan secara statistik dibandingkan dengan kelompok I. Selain itu kadar glukosa darah kelompok III mendekati kadar glukosa darah tikus sehat kelompk I dibandingkan dengan kelompok II. Glibenklamid mempunyai mekanisme kerja pada sel $\beta$ pankreas, dimana dapat menstimulus sekresi insulin melalui penutupan kanal $\mathrm{K}+$ sehingga terjadi depolarisasi dan insulin dikeluarkan melalui eksositosis. ${ }^{10}$ Peningkatan sekresi insulin karena glibenklamid juga berdampak pada berat badan pada hari ke-0 sampai hari ke-28 yang menunjukan kenaikan berat badan tikus. Kelompok IV yang menerima perlakuan kombinasi jus Aloe vera dan glibenklamid memperlihatkan penurunan glukosa yang signifikan secara statistik dibandingkan kelompok III yang hanya menerima glibenklamid. Selain itu kadar glukosa darah kelompok IV lebih mendekati kadar glukosa darah tikus sehat kelompk I dibandingkan dengan kelompok III.

Pelakuan kombinasi yang diterima tikus membuat tikus mempunyai efek hipoglikemik dari dua jenis yang berbeda. Pertama dari glibenklamid yang mempunyai efek peningkatan sekresi insulin dan Aloe vera yang memiliki dua zat aktif yang memiliki efek hipoglikemik yaitu kromium dan alprogen. Mekanisme kromium dalam menurunkan glukosa darah belum begitu jelas. Namun menurut penelitian yang telah dilakukan, kromium dapat merangsang sekresi insulin oleh sel beta pankreas. Kromium dapat meningkatkan serotonin yang berperan dalam peningkatan ambilan glukosa oleh otot dan sebuah penelitian baru menunjukan serotonin mempunyai efek terhadap sekresi insulin. ${ }^{11}$ Efek lain kromium yaitu memperbaiki resistensi insulin dengan cara berikatan pada reseptor insulin, kemudian kromium meningkatkan aktivitas tirosin kinase, IRS-1 (Insulin Reseptor
Substrat-1) sehingga meningkatkan aktivitas GLUT 4 dalam ambilan glukosa untuk dijadikan sebagai energi. ${ }^{10,11,13}$

Alprogen dalam Aloe vera mampu menurunkan kadar glukosa darah dengan cara menghambat absorsi glukosa pada usus. Mekanismenya dengan menghambat kerja $\mathrm{Ca} 2+$, dimana normalnya kalsium berada di lumen usus akan membawa glukosa masuk ke sel usus dan selanjutnya glukosa akan dieksositasis oleh SGLT 1 (Sodium Glukosa Transpor 1) yang berfungsi mengangkut glukosa melewati membran usus. Jika kalsium dihambat maka SGLT 1 tidak dapat mengeluarkan glukosa dan tidak terjadi perpindahan glukosa menuju pembuluh darah. ${ }^{6}$ Aloe vera dapat mencegah kematian sel $\beta$ serta pemulihan sel $\beta$ yang rusak. ${ }^{12,14}$

\section{SIMPULAN DAN SARAN}

\section{Simpulan}

Pemberian kombinasi jus Aloe vera sebesar 3,6 $\mathrm{ml} / 200 \mathrm{~g} \mathrm{BB} /$ hari dengan glibenklamid $0,18 \mathrm{mg} / 200$ g BB/hari mampu menurunkan kadar glukosa pada model tikus diabetes yang diinduksi dengan streptozotosin dan nikotinamid dan signifikan secara statistik

\section{Saran}

Perlu dilakukan penelitian lebih lanjut dengan menggunakan ekstrak Aloe vera yang dikombinasikan dengan glibenklamid terhadap penurunan kadar glukosa darah pada tikus diabetes yang diinduksi streptozotosin dan nikotinamid.

\section{KONFLIK KEPENTINGAN}

Penulis menyatakan tidak terdapat konflik kepentingan terkait publikasi dari artikel ini.

\section{PENDANAAN}

Penelitian ini tidak mendapatkan hibah dana dari pemerintah ataupun lembaga swasta lainnya.

\section{ETIKA DALAM PENELITIAN}

Penelitian ini telah mendapatkan surat kelayakan etik dari Komisi Etika Penelitian Fakultas Kedokteran dan Ilmu Kesehatan Universitas Muhammadiyah Yogyakarta dengan nomere referensi 020/EP-FKIK-UMY/I/2015

\section{DAFTAR PUSTAKA}

1. Perkumpulan Endrokrinologi Indonesia. Konsensus Pengolahan Dan Pencegahan Diabetes Melitus Tipe 2 Di Indonesia. PERKENI: Jakarta; 2011: p. 15-26.

2. World Health Organization. Diabetes Report. Geneva: WHO; 2014 
3. Wijaya M, Sari G, Tinduh D. Hyperglycemia caused reduction of cortical bone thickness in streptozotocininduced diabetic rat. Bali Medical Journal. 2017;6(1):161163. DOI:10.15562/bmj.v6i1.393

4. Artha IMJR, Bhargah A, Dharmawan NK, Pande UW, Triyana KA, Yuwono J, Prabawa IPY, Manuaba IBAP, Rina IK. High level of individual lipid profile and lipid ratio as a predictive marker of poor glycemic control in type-2 diabetes mellitus. Vascular Health and Risk Management. 2019;15:149-157. Doi: http://doi.org/10.2147/VHRM. S209830.

5. Wulandah AF. Pengaruh Pemberian Sari Mengkudu (Norinda citrifolia Linn.) Terhadap Glibenklamid Dalam Menurunkan Kadar Glukosa DarahTikus Jantan Yang Dibuat Diabetes. Pharmaceutical Science and Research. 2011;9(1):1-11.

6. Mustofa, Yunistari A, Marianti A. Efek Pemberian Jus Lidah Buaya Terhadap Kadar Gluosa Darah Tikus Putih. Unnes J Life Sci. 2012;1(1):1-6.

7. Triwidyana A. Efek Ekstrak Etanol 70 \% Daun Liga Buaya (Aloe vera) Terhadap Penurunan Kadar Glukosa Darah Pada Tikus Putih (Rattus novergicus strain wistar) Yang Dibebani Glukosa. Universitas Islam Indonesia: Yogyakarta. 2013; p. 1-10

8. Juneby BH. Aloe Barbadensis Miller. Sweden: Uppsala University; 2011; p. 4-9.

9. Szkudelski T. Streptozotocin- nicotinamide- induced diabetes in the rat. Characteristics of the experimental model. Exp Biol Med. 2012;237(5):481-90.
10. Katzung BG. Basic and Clinical Pharmacology 10th Edition. Singapore: TheMcGraw Hill Companies; 2007: p. 715-722.

11. Ardiansyah, Shirkawa H, Inagawa Y, Koseki T, Komai M. Regulation of Blood Pressure and Glucose Metabolism Induced by L- tryptophan In Stroke-Prone Spontaneously Hipertensive Rats. Nutr Metab (Lond). 2011;28(1):45-47

12. Balk EM, Tastioni A, Linchstein AH, Lau J, Pittas AG. Effects Of Chromium Supplementation On Glucose Metabolism and Lipid. Diabetes Care. 2007;30(8):2154-63.

13. Jain SK, Croad JL, Velusamy T, Rains JL, Bull R. Chromium Dinicocysteinate Supplementation Can Lower Blood Glucose, CRP, MCP-1, ICAM-1, Creatinine, Apparently Mediated By Elevated Blood VitamiN C and Adiponectin and Inhibition Of NfkB, Akt, and Glut-2 In Liver Of Zucker Diabetic Fatty Rats. Mol Nutr Food Res. 2010;54(9):137180.

14. Sharma B, Sufiyan S, Gurudayal R, Manisha C, Gaurav S. Hypoglicemic and Hepatoprotective Effects of Procesed Aloe vera Gel In A Mice Model Of Alloxan Induced Diabetes Melitus. Journal of Diabetes and Metabolism. 2011;4(9):1-6.

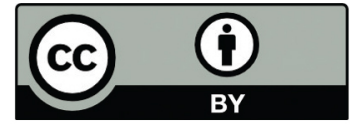

This work is licensed under a Creative Commons Attribution 